Original Article

\title{
Classification of the Efficacy of Herbal Medicine Alterations in Neuronal Hypoxia Models through Analysis of Gene Expression
}

\author{
Joo-won Hwang ${ }^{1}$, Gil-cho Shin ${ }^{1}$, Il-su Moon ${ }^{2}$ \\ ${ }^{1}$ Dept. of Internal Medicine, College of Korean Medicine, Dongguk University \\ ${ }^{2}$ Dept. of Anatomy, College of Medicine, Dongguk University
}

\begin{abstract}
Objectives: cDNA microarray is an effective method to snapshot gene expression. Functional clustering of gene expressions can identify herbal medicine mechanisms. Much microarray data is available for various herbal medicines. This study compares regulated genes with herbal medicines to evaluate the nature of the drugs.

Methods: Published microarray data were collected. Total RNAs were prepared from dissociated hippocampal dissociate cultures which were given hypoxic shock in the presence of each herbal medicine. Up- or downregulated genes higher than Global M value 0.5 were selected, clustered in functional groups, and compared with various herbal treatments.

Results: 1. Akt2 was upregulated by Acorus gramineus SOLAND, Arisaema amurense var. serratum $\mathrm{N}_{\mathrm{AKAI}}$ and Coptis chinensis $\mathrm{F}_{\mathrm{RANCH}}$, and they belong to Araceae herb. 2. Nf- $\kappa \mathrm{bl}, \mathrm{Cd} 5, \mathrm{Gn} \gamma 7$ and Sgnel were upregulated by Arisaema amurense var. serratum $\mathrm{N}_{\mathrm{AKAI}}$, Coptis chinensis $\mathrm{F}_{\mathrm{RANCH}}$ and Rheum coreanum $\mathrm{N}_{\mathrm{AKAI}}$. 3. Woohwangcheongsim -won, Sohaphyang-won and Scutellaria baicalensis $\mathrm{G}_{\mathrm{EORGI}}$ downregulated Scp2 and upregulated Tsc2. Woohwangcheongsim-won and Sohaphyang-won upregulated Hbal and downregulated Myf6. 4. Sohaphyang-won and Scutellaria baicalensis $\mathrm{G}_{\mathrm{EORGI}}$ downregulated Slc12a1. 5. Woohwangcheongsim-won and Arisaema amurense var. serratum $\mathrm{N}_{\mathrm{AKAI}}$ upregulated Rar $\alpha$, Woohwangcheongsim-won and Coptis chinensis $\mathrm{F}_{\mathrm{RANCH}}$ downregulated Rab5a and Pdgfr $\alpha$, and Woohwangcheongsim-won and Rheum coreanum $\mathrm{N}_{\mathrm{AKAI}}$ upregulated Plc $\gamma 1$ and downregulated Pla2g1b and Slc10a1.

Conclusions: By clustering microarray, genes are commonly identified to be either up- or downregulated. These results will provide new information to understand the efficacy of herbal medicines and to classify them at the molecular level.
\end{abstract}

$\overline{\text { Key Words }}$ : Hypoxia, apoptosis, gene expression, microarray

\section{Introduction}

Apoptosis, due to reactive oxygen species (ROS), serves an important role in degenerative disorders of the nervous system. Because apoptosis results in numerous semi-permanent side effects even after treatment, there has been a lot of research on a treatment method that can effectively decrease apoptosis $^{1,2)}$.

Research on discovering biological, pathological mechanisms through genetic regulation has been increasing since the completion of the genetic map of several species, including that of human beings ${ }^{3}$,

4). Microarray, a technique to find the function and

\footnotetext{
- Received : 16 November 2014

- Revised : 17 December 2014

- Accepted : 17 December 2014

- Correspondence to : Gil-cho Shin

Dept. of Internal Medicine, Dongguk University Bundang Korean Medicine Hospital,

268, Buljeong-ro, Bundang-gu, Seongnam-si, Gyeonggi-do, Korea

Tel : +82-31-710-3710, Fax : +82-31-710-3780, E-mail : shingcho@naver.com
} 
structure of genes, makes it possible to determine the general expression of an entire gene within a cell. It is a major tool in function genomics research, ${ }^{5,6}$.

Previous experimental research reports that some herbal medicines or extracts delay apoptosis due to hypoxia, and the medicine's gene expression has been studied through the microarray. By analyzing the function of genes where alteration in expression occurred and the neuron's genetic expression alteration by each medicine and treatment, it is possible to infer the medicine's mechanism ${ }^{7-14}$. However, although each herbal medicine may have functioned by different mechanisms, there has been no report about the instance of mutual comparison and interpretation by merging Korean medicine theory.

The author analyzed experimental studies that observed expressed genes from herbal medicines or extracts in neurons where apoptosis has occurred under hypoxia and interpreted the influence on gene function related to the medicine's neuron protection and anti-oxidation from the point of view of Korean medicine.

\section{Research Target and Method}

\section{Research Target}

Clustering is an analyzing method that classifies the genes that have been identified with expression alteration through microarray by similar groups. Hierarchical clustering is a method that groups genes with similar characteristics and analyzes them. It is useful in understanding a herbal medicine and treatment's properties based on the expressed genes $^{16)}$.

This study limited its target to experimental research that used clustering to investigate altered expression of genes through microarray after inducing apoptosis in neurons under hypoxia and treating with herbal medicines or extracts.

As a result, with similar analyzing methods, we detected results from observing gene alteration. We compared and analyzed based on the research findings that use Acorus gramineus $\mathrm{S}_{\mathrm{OLAND}}{ }^{7}$, Arisaema amurense var. serratum $\mathrm{N}_{\mathrm{AKAI}}{ }^{8)}$, Pinellia ternata B $_{\text {REIT. }}{ }^{9)}$, Scutellaria baicalensis $\mathrm{G}_{\mathrm{EORGI}}{ }^{10)}$, Coptis chinensis $\mathrm{F}_{\mathrm{RANCH}}{ }^{11)}$, Rheum coreanum $\mathrm{N}_{\mathrm{AKAI}}{ }^{12)}$, Woohwangcheongsim-won ${ }^{13)}$, and Sohaphyang-won ${ }^{14)}$, that are frequently used in cerebrovascular disease.

\section{Research Method}

Among the genes expressed through microarray, we compared expressed genes with global $\mathrm{M}$ figure higher than +0.5 and lower than -0.5 . We compared Acorus gramineus $\mathrm{S}_{\mathrm{OLAND}}$, Arisaema amurense var. serratum $\mathrm{N}_{\mathrm{AKAI}}$, and Pinellia ternata $\mathrm{B}_{\mathrm{REIT}}$, which belong to the araceae herb and has function of dispel Dam-eum (phlegm-retained fluid); and compared Pinellia ternata $\mathrm{B}_{\mathrm{REIT}}$., Coptis chinensis $\mathrm{F}_{\mathrm{RANCH}}$, and Rheum coreanum $\mathrm{N}_{\mathrm{AKAI}}$ that are expressed in similar class; and observed whether there is an overlap of expressed genes between different medicines. Then, we compared the gene expression of Woohwangcheongsim -won and Sohaphyang-won that are used for acute stroke and observed an overlap of expressed genes with other medicines.

\section{Results}

\section{Comparison of microarray methods}

Table 1 shows the microarray method and the mRNA separation process from neurons induced of apoptosis due to ischemic damage from each study.

\section{Clustering of herbal medicine's genes}

Table 2 shows the classification of each herbal medicine based on reported research findings. We excluded findings of global $M$ figures within \pm 0.5 because there is a difference in the global $\mathrm{M}$ figure which is the standard for each study. 
Table 1. Comparison of Experimental Procedures for Microarrays of Each Herb Extract or Composites.

\begin{tabular}{|c|c|c|c|c|c|c|}
\hline & Concentration & $\begin{array}{l}\text { Added } \\
\text { DIV }\end{array}$ & $\begin{array}{l}\text { Inducing } \\
\text { hypoxia }\end{array}$ & Microarray platform & Company & Reference \\
\hline Acorus gramineus $\mathrm{S}_{\mathrm{OLAND}}$ & $10 \mu \mathrm{g} / \mathrm{ml}$ & DIV 12 & DIV 14 & TwinChip $^{\text {TM }}$ Rat-5K & $\begin{array}{l}\text { Digital } \\
\text { Genomics }\end{array}$ & $\begin{array}{l}\text { Park et al. } \\
(2007)^{7}\end{array}$ \\
\hline $\begin{array}{c}\text { Arisaema amurense var. } \\
\text { serratum } \mathrm{N}_{\mathrm{AKAI}}\end{array}$ & $10 \mu \mathrm{g} / \mathrm{ml}$ & DIV 12 & DIV 14 & TwinChip $^{\text {TM }}$ Rat-5K & $\begin{array}{c}\text { Digital } \\
\text { Genomics }\end{array}$ & $\begin{array}{l}\text { Koh et al. } \\
(2003)^{8}\end{array}$ \\
\hline Pinellia ternata $\mathrm{B}_{\text {REIT. }}$ & $2.5 \mu \mathrm{g} / \mathrm{ml}$ & DIV 12 & DIV 14 & TwinChip $^{\text {TM }}$ Rat-5K & $\begin{array}{c}\text { Digital } \\
\text { Genomics }\end{array}$ & $\begin{array}{l}\text { Kwon et al. } \\
\quad(2005)^{9}\end{array}$ \\
\hline Scutellaria baicalensis $\mathrm{G}_{\mathrm{EORGI}}$ & $20 \mu \mathrm{g} / \mathrm{ml}$ & DIV 12 & DIV 14 & TwinChip $^{\mathrm{TM}}$ Rat-5K & $\begin{array}{l}\text { Digital } \\
\text { Genomics }\end{array}$ & $\begin{array}{l}\text { Kim et al. } \\
(2004)^{10}\end{array}$ \\
\hline Coptis chinensis $\mathrm{F}_{\mathrm{RANCH}}$ & $2.5 \mu \mathrm{g} / \mathrm{ml}$ & DIV 12 & DIV 14 & TwinChip $^{\text {TM }}$ Rat-5K & $\begin{array}{c}\text { Digital } \\
\text { Genomics }\end{array}$ & $\begin{array}{l}\text { Hwang et al. } \\
\qquad(2005)^{11}\end{array}$ \\
\hline Rheum coreanum $\mathrm{N}_{\mathrm{AKAI}}$ & $2.5 \mu \mathrm{g} / \mathrm{ml}$ & DIV 10 & DIV 13 & $\begin{array}{l}\text { Rat } 44 \mathrm{~K} \text { 4-Plex } \\
\text { Gene Expression } \\
\text { platform(Agilent) }\end{array}$ & $\begin{array}{c}\text { Digital } \\
\text { Genomics }\end{array}$ & $\begin{array}{l}\text { Lee et al. } \\
(2009)^{12}\end{array}$ \\
\hline Woohwangcheongsim-won & $20 \mu \mathrm{g} / \mathrm{ml}$ & DIV 12 & DIV 14 & TwinChip $^{\mathrm{TM}}$ Rat-5K & $\begin{array}{c}\text { Digital } \\
\text { Genomics }\end{array}$ & $\begin{array}{l}\text { Park et al. } \\
(2004)^{13}\end{array}$ \\
\hline Sohaphyang-won & $20 \mu \mathrm{g} / \mathrm{ml}$ & DIV 12 & DIV 14 & TwinChip $^{\mathrm{TM}}$ Rat-5K & $\begin{array}{l}\text { Digital } \\
\text { Genomics }\end{array}$ & $\begin{array}{l}\text { Paik et al. } \\
(2004)^{14}\end{array}$ \\
\hline
\end{tabular}

All experiments were performed using E18 rat embryonic hippocampal neurons in culture grown in the neurobasal medium supplemented with B27.

All components were diluted or extracted with water and added directly to the medium.

* In all cases hypoxic shock was given for $3 \mathrm{hrs}$ in $2 \% \mathrm{O} 2 / 5 \% \mathrm{CO} 2$ and total mRNAs were extracted $24 \mathrm{hrs}$ after shock.

Table 2. The Number of Genes Up- or Downregulated by Each Treatment

\begin{tabular}{|c|c|c|c|c|c|c|c|c|c|}
\hline & & $\begin{array}{c}\text { Acorus } \\
\text { gramineus } \\
\text { SOLAND }\end{array}$ & $\begin{array}{c}\text { Arisaema } \\
\text { amurense } \\
\text { var. } \\
\text { serratum } \\
\text { NAKAI }\end{array}$ & $\begin{array}{c}\text { Pinellia } \\
\text { ternata } \\
\text { BREIT. }\end{array}$ & $\begin{array}{c}\text { Scutellaria } \\
\text { baicalensis } \\
\text { GEORGI }\end{array}$ & $\begin{array}{c}\text { Coptis } \\
\text { chinensis } \\
\text { FRANCH }\end{array}$ & $\begin{array}{c}\text { Rheum } \\
\text { coreanum } \\
\text { NAKAI }\end{array}$ & $\begin{array}{l}\text { Woohwangche } \\
\text {-ongsim-won }\end{array}$ & $\begin{array}{c}\text { Sohaphyang } \\
\text {-won }\end{array}$ \\
\hline \multirow{2}{*}{ Apoptosis } & upregulated & & 1 & & & 12 & 6 & & \\
\hline & downregulated & 1 & & 2 & & 5 & 6 & & \\
\hline \multirow{2}{*}{$\begin{array}{c}\text { Growth \& } \\
\text { maintenance }\end{array}$} & upregulated & 6 & 17 & & 2 & & & 6 & 3 \\
\hline & downregulated & 8 & 4 & & 3 & & & 18 & 3 \\
\hline \multirow{2}{*}{ Cell cycle } & upregulated & 1 & 2 & 1 & & 15 & 5 & & \\
\hline & downregulated & & 1 & 1 & 1 & 15 & 8 & 1 & \\
\hline \multirow{2}{*}{$\begin{array}{l}\text { Response to } \\
\text { stress }\end{array}$} & upregulated & 1 & 5 & 1 & & 27 & 17 & 5 & \\
\hline & downregulated & & & 1 & & 16 & 11 & 2 & \\
\hline \multirow{2}{*}{$\begin{array}{c}\text { Signal } \\
\text { transduction }\end{array}$} & upregulated & & 12 & 3 & 1 & 56 & 22 & 5 & 1 \\
\hline & downregulated & 2 & 2 & 2 & 1 & 41 & 16 & 6 & \\
\hline \multirow{2}{*}{ Transcription } & upregulated & 1 & 4 & 1 & 1 & 20 & 11 & 2 & \\
\hline & downregulated & & 2 & 3 & & 15 & 17 & 5 & 1 \\
\hline \multirow{2}{*}{$\begin{array}{c}\text { Physiological } \\
\text { process }\end{array}$} & upregulated & & & 8 & & 185 & 24 & & \\
\hline & downregulated & & & 16 & & 129 & 12 & & \\
\hline \multirow{2}{*}{$\begin{array}{l}\text { Immune } \\
\text { response }\end{array}$} & upregulated & & 3 & 1 & & 19 & 11 & & 1 \\
\hline & downregulated & 1 & & & & 10 & 6 & 3 & \\
\hline
\end{tabular}




\section{Analysis of gene alternation between medicines}

We investigated genes that demonstrate similar alteration between medicines.

1) Comparison of global $\mathrm{M}$ figure of Acorus gramineus $\mathrm{S}_{\mathrm{OLAND}}$ and Arisaema amurense var. serratum $\mathrm{N}_{\mathrm{AKAI}}$

Thymoma viral proto-oncogene 2 (Akt2) altered in the same direction in the research on Acorus gramineus SoLAND and Arisaema amurense var. serratum $\mathrm{N}_{\mathrm{AKAI}}$, which belong to the araceae herb. Table 3 shows the result of the analysis.

2) Comparison of global $\mathrm{M}$ figure of Acorus gramineus $\mathrm{S}_{\mathrm{OLAND}}$ and Coptis chinensis $\mathrm{F}_{\mathrm{RANCH}}$

Akt 2 altered in the same direction in the research on Acorus gramineus $\mathrm{S}_{\mathrm{OLAND}}$ and Coptis chinensis $\mathrm{F}_{\mathrm{RANCH}}$. Table 4 shows the result of the analysis.

3) Comparison of global $\mathrm{M}$ figure of Coptis chinensis $\mathrm{F}_{\mathrm{RANCH}}$ and Pinellia ternata $\mathrm{B}_{\mathrm{REIT}}$.

$\mathrm{CD} 3$ molecule, delta $(\mathrm{Cd} 3 \delta)$ altered in the same direction in the research on Coptis chinensis $\mathrm{F}_{\mathrm{RANCH}}$

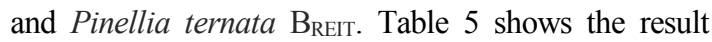
of the analysis.

4) Comparison of global $\mathrm{M}$ figure of Coptis chinensis $\mathrm{F}_{\mathrm{RANCH}}$ and Arisaema amurense var. serratum $\mathrm{N}_{\mathrm{AKAI}}$

A total of 25 types of genes were altered in the identical direction. Table 6 shows the result of the analysis. 2 types of genes related to apoptosis, 13 types of genes related to growth \& maintenance, 2

Table 3. An Upregulated Gene by Both Acorus gramineus SOLAND and Arisaema amurense var. serratum NAKAI

\begin{tabular}{cccc}
\hline & & Acorus gramineus Soland & Arisaema amurense var. serratum $\mathrm{N}_{\text {AKAI }}$ \\
\hline Growth \& maintenance & $\begin{array}{c}\text { upregulated } \\
\text { downregulated }\end{array}$ & 1 \\
Cell cycle & upregulated & - & 1 \\
& downregulated & -
\end{tabular}

Table 4. An Upregulated Gene by Both Acorus gramineus SOLAND and Coptis chinensis FRANCH

\begin{tabular}{|c|c|c|c|}
\hline & & Acorus gramineus $\mathrm{S}_{\mathrm{OLAND}}$ & Coptis chinensis $\mathrm{F}_{\mathrm{RANCH}}$ \\
\hline \multirow{2}{*}{ Growth \& maintenance } & upregulated & 1 & \\
\hline & downregulated & - & \\
\hline \multirow{2}{*}{ Cell cycle } & upregulated & 1 & \\
\hline & downregulated & - & \\
\hline
\end{tabular}

Table 5. An Upregulated Gene by Both Coptis chinensis FRANCH and Pinellia ternata BREIT

\begin{tabular}{|c|c|c|c|}
\hline & & Coptis chinensis $\mathrm{F}_{\mathrm{RANCH}}$ & Pinellia ternata $\mathrm{B}_{\mathrm{REIT}}$. \\
\hline \multirow{2}{*}{ Signal transduction } & upregulated & 1 & \\
\hline & downregulated & - & \\
\hline \multirow{2}{*}{ Physiological process } & upregulated & 1 & \\
\hline & downregulated & - & \\
\hline \multirow{2}{*}{ Immune response } & upregulated & 1 & \\
\hline & downregulated & - & \\
\hline
\end{tabular}


types of genes related to cell cycle, 4 types of genes related to response to stress, 11 types of genes related to signal transduction, 3 types of genes related to transcription, 18 types of genes related to physiological process, and 3 types of genes related to immune response.

5) Comparison of global $\mathrm{M}$ figure of Coptis chinensis $\mathrm{F}_{\mathrm{RANCH}}$ and Rheum coreanum $\mathrm{N}_{\mathrm{AKAI}}$

A total of 29 types of genes were altered in the identical direction. Table 7 shows the result of the analysis. There were 2 types of genes related to apoptosis, 3 types of genes related to cell cycle, 10 types of genes related to response to stress, 11 types of genes related to signal transduction, 5 types of genes related to transcription, 17 types of genes related to physiological process, and 7 types of genes related to immune response.

6) Comparison of global M figure of Arisaema amurense var. serratum $\mathrm{N}_{\mathrm{AKAI}}$ and Rheum coreanum $\mathrm{N}_{\mathrm{AKAI}}$
A total of 5 types of genes were altered in the identical direction. Table 8 shows the result of the analysis. There were 1 type of gene related to apoptosis, 1 type of gene related to growth \& maintenance, 2 types of genes related to response to stress, 3 types of genes related to signal transduction, 2 types of genes related to transcription, 2 types of genes related to physiological process, and 2 types of genes related to immune response.

7) Comparison of global $\mathrm{M}$ figure of Arisaema amurense var. serratum $\mathrm{N}_{\mathrm{AKAI}}$, Coptis chinensis $\mathrm{F}_{\mathrm{RANCH}}$ and Rheum coreanum $\mathrm{N}_{\mathrm{AKAI}}$

A total of 4 types of genes were altered in the identical direction in Arisaema amurense var. serratum $\mathrm{N}_{\mathrm{AKAI}}$, Coptis chinensis $\mathrm{F}_{\mathrm{RANCH}}$, and Rheum coreanum $\mathrm{N}_{\mathrm{AKAI}}$. Table 9 shows the result of the analysis.

\section{Comparison between Woohwangcheongsim -won and Sohaphyang-won and each}

Table 6. Genes Up- or Downregulated by Both Coptis chinensis FRANCH and Arisaema amurense var. serratum NAKAl

\begin{tabular}{|c|c|c|c|}
\hline & & Coptis chinensis $\mathrm{F}_{\mathrm{RANCH}}$ & Arisaema amurense var. serratum $\mathrm{N}_{\mathrm{AKAI}}$ \\
\hline \multirow{2}{*}{ Apoptosis } & upregulated & & 2 \\
\hline & downregulated & & - \\
\hline \multirow{2}{*}{ Growth \& maintenance } & upregulated & & 13 \\
\hline & downregulated & & - \\
\hline \multirow{2}{*}{ Cell cycle } & upregulated & & 2 \\
\hline & downregulated & & - \\
\hline \multirow{2}{*}{ Response to stress } & upregulated & & 4 \\
\hline & downregulated & & - \\
\hline \multirow{2}{*}{ Signal transduction } & upregulated & & 10 \\
\hline & downregulated & & 1 \\
\hline \multirow{2}{*}{ Transcription } & upregulated & & 3 \\
\hline & downregulated & & - \\
\hline \multirow{2}{*}{ Physiological process } & upregulated & & 18 \\
\hline & downregulated & & - \\
\hline \multirow{2}{*}{ Immune response } & upregulated & & 3 \\
\hline & downregulated & & - \\
\hline
\end{tabular}




\section{medicine}

We compared the genes that are identical from the research findings on Woohwangcheongsim-won and Sohaphyang-won which are used for acute stroke and compared the genes that were up- and down-regulated in the same direction from the research findings with other medicines.

Table 7. Genes Up- or Downregulated by Both Coptis chinensis FRANCH and Rheum coreanum NAKAI

\begin{tabular}{|c|c|c|c|}
\hline & & Coptis chinensis $\mathrm{F}_{\mathrm{RANCH}}$ & Rheum coreanum $\mathrm{N}_{\text {AKAI }}$ \\
\hline \multirow{2}{*}{ Apoptosis } & upregulated & 2 & \\
\hline & downregulated & - & \\
\hline \multirow{2}{*}{ Cell cycle } & upregulated & 3 & \\
\hline & downregulated & - & \\
\hline \multirow{2}{*}{ Response to stress } & upregulated & 10 & \\
\hline & downregulated & - & \\
\hline \multirow{2}{*}{ Signal transduction } & upregulated & 10 & \\
\hline & downregulated & 1 & \\
\hline \multirow{2}{*}{ Transcription } & upregulated & 4 & \\
\hline & downregulated & 1 & \\
\hline \multirow{2}{*}{ Physiological process } & upregulated & 17 & \\
\hline & downregulated & - & \\
\hline \multirow{2}{*}{ Immune response } & upregulated & 6 & \\
\hline & downregulated & 1 & \\
\hline
\end{tabular}

Table 8. Genes Upregulated by Arisaema amurense var. serratum NAKAl, and Rheum coreanum NAKAl

\begin{tabular}{|c|c|c|c|}
\hline & & Coptis chinensis $\mathrm{F}_{\mathrm{RANCH}}$ & Rheum coreanum $\mathrm{N}_{\mathrm{AKAI}}$ \\
\hline \multirow{2}{*}{ Apoptosis } & upregulated & & 1 \\
\hline & downregulated & & - \\
\hline \multirow{2}{*}{ Growth \& maintenance } & upregulated & & 1 \\
\hline & downregulated & & - \\
\hline \multirow{2}{*}{ Cell cycle } & upregulated & & \\
\hline & downregulated & & \\
\hline \multirow{2}{*}{ Response to stress } & upregulated & & 1 \\
\hline & downregulated & & - \\
\hline \multirow{2}{*}{ Signal transduction } & upregulated & & 3 \\
\hline & downregulated & & - \\
\hline \multirow{2}{*}{ Transcription } & upregulated & & 2 \\
\hline & downregulated & & - \\
\hline \multirow{2}{*}{ Physiological process } & upregulated & & 2 \\
\hline & downregulated & & - \\
\hline \multirow{2}{*}{ Immune response } & upregulated & & 2 \\
\hline & downregulated & & - \\
\hline
\end{tabular}


1) A total of 4 types of genes were identical. Table 10 shows the result of the analysis. There were 3 types of genes related to growth \& maintenance, 1 type of gene related to signal transduction, and 1 type of gene related to transcription.

2) Comparison of global $M$ figure of Woohwangcheongsim-won and Scutellaria baicalensis GERGI

Tuberous sclerosis 2 (Tsc2) and sterol carrier protein 2 (Scp2) were altered in the identical direction in the research on Woohwangcheongsim -won and Scutellaria baicalensis GEORGI. Table 11 shows the analysis result.

3) Comparison of global M figure of Sohaphyang -won and Scutellaria baicalensis $\mathrm{G}_{\mathrm{EORGI}}$

A total of 3 types of genes were identical. Table 12 shows the result of the analysis. There were 3 types of genes related to growth \& maintenance and 1 type of gene related to signal transduction. Fig. 4 shows the genes that are upregulated in the three studies on Woohwangcheongsim-won, Sohaphyang -won and Scutellaria baicalensis $\mathrm{G}_{\mathrm{EORGI}}$.

4) Comparison of global $M$ figure of Woohwangcheongsim-won and Arisaema amurense

Table 9. Genes Upregulated by Arisaema amurense var. serratum NAKAl, Coptis chinensis FRANCH and Rheum coreanum NAKAl

\begin{tabular}{|c|c|c|c|c|}
\hline & & $\begin{array}{c}\text { Arisaema amurense var. } \\
\text { serratum } \mathrm{N}_{\mathrm{AKAI}}\end{array}$ & $\begin{array}{l}\text { Coptis chinensis } \\
\mathrm{F}_{\mathrm{RANCH}}\end{array}$ & $\begin{array}{c}\text { Rheum coreanum } \\
\mathrm{N}_{\mathrm{AKAI}}\end{array}$ \\
\hline \multirow{2}{*}{ Apoptosis } & upregulated & & 1 & \\
\hline & downregulated & & - & \\
\hline \multirow{2}{*}{ Growth \& maintenance } & upregulated & & 1 & \\
\hline & downregulated & & - & \\
\hline \multirow{2}{*}{ Response to stress } & upregulated & & 2 & \\
\hline & downregulated & & - & \\
\hline \multirow{2}{*}{ Signal transduction } & upregulated & & 3 & \\
\hline & downregulated & & - & \\
\hline \multirow{2}{*}{ Transcription } & upregulated & & 1 & \\
\hline & downregulated & & - & \\
\hline \multirow{2}{*}{ Physiological process } & upregulated & & 1 & \\
\hline & downregulated & & - & \\
\hline \multirow{2}{*}{ Immune response } & upregulated & & 2 & \\
\hline & downregulated & & - & \\
\hline
\end{tabular}

Table 10. Genes Up- or Downregulated by Both Woohwangcheongsim-won and Sohaphyang-won

\begin{tabular}{|c|c|c|c|}
\hline & & Woohwangcheongsim-won & Sohaphyang-wol \\
\hline \multirow{2}{*}{ Growth \& maintenance } & upregulated & 2 & \\
\hline & downregulated & 1 & \\
\hline \multirow{2}{*}{ Signal transduction } & upregulated & 1 & \\
\hline & downregulated & - & \\
\hline \multirow{2}{*}{ Transcription } & upregulated & - & \\
\hline & downregulated & 1 & \\
\hline
\end{tabular}




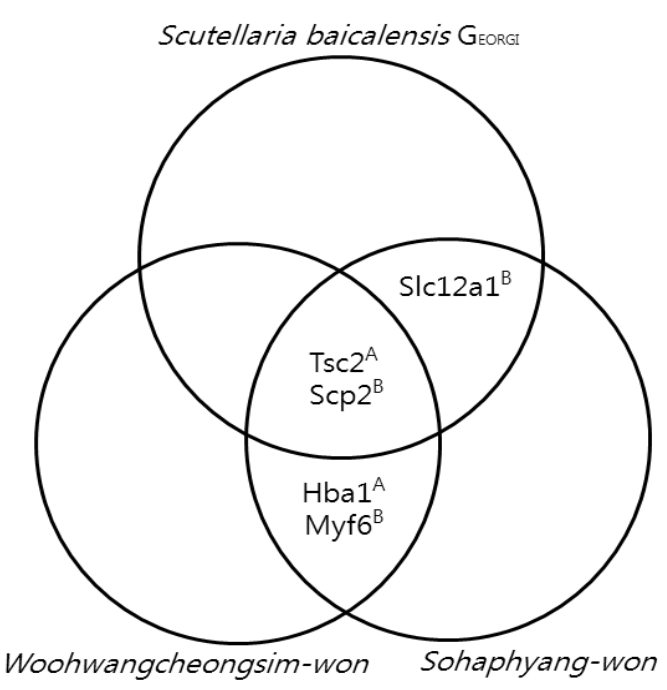

Fig. 1. Gene distribution expressed by Scutellaria baicalensis GEORGI, Woohwangcheongsim-won and Sohaphyang -won. A. Upregulated genes. B. downregulated genes. var. serratum $\mathrm{N}_{\mathrm{AKAI}}$

Retinoic acid receptor, alpha $(\operatorname{Rar} \alpha)$ was altered in the identical direction in the research on Woohwangcheongsim-won and Arisaema amurense var. serratum $\mathrm{N}_{\mathrm{AKAI}}$. Table 13 shows the analysis result.

5) Comparison of global $\mathrm{M}$ figure of Woohwangcheongsim-won and Coptis chinensis $\mathrm{F}_{\mathrm{RANCH}}$

Ras-related protein $4 \mathrm{a}$ (Rab4a) and platelet derived growth factor receptor, alpha polypeptide (Pdgfr $\alpha$ ) were altered in the identical direction in the research on Woohwangcheongsim-won and Coptis chinensis $\mathrm{F}_{\mathrm{RANCH}}$. Table 14 shows the analysis result.

6) Comparison of global $\mathrm{M}$ figure of Woohwangcheongsim-won and Rheum coreanum $\mathrm{N}_{\text {AKAI }}$

Table 11. Genes Up- or Downregulated by Both Woohwangcheongsim-won and Scutellaria baicalensis GEORGI

\begin{tabular}{cccc}
\hline & & Woohwangcheongsim-won & Scutellaria baicalensis $\mathrm{G}_{\mathrm{EORGI}}$ \\
\hline \multirow{2}{*}{ Growth \& maintenance } & $\begin{array}{c}\text { upregulated } \\
\text { downregulated }\end{array}$ & 1 & \\
\multirow{2}{*}{ Signal transduction } & $\begin{array}{c}\text { upregulated } \\
\text { downregulated }\end{array}$ & 1 & 1 \\
\hline
\end{tabular}

Table 12. Genes Up- or Downregulated by Both Sohaphyang-won and Scutellaria baicalensis GEORGI

\begin{tabular}{cccc}
\hline & Sohaphyang-won & Scutellaria baicalensis $\mathrm{G}_{\mathrm{EORG}}$ \\
\hline \multirow{2}{*}{ Growth \& maintenance } & $\begin{array}{c}\text { upregulated } \\
\text { downregulated }\end{array}$ & 1 & 2 \\
\hline \multirow{2}{*}{ Signal transduction } & $\begin{array}{c}\text { upregulated } \\
\text { downregulated }\end{array}$ & 1 & \\
\hline
\end{tabular}

Table 13. An upregulated Gene by Both Woohwangcheongsim-won and Arisaema amurense var. serratum NAKAI

\begin{tabular}{|c|c|c|c|}
\hline & & Woohwangcheongsim-won & Arisaema amurense var. serratum $\mathrm{N}_{\mathrm{AKAI}}$ \\
\hline \multirow{2}{*}{ Apoptosis } & upregulated & & 1 \\
\hline & downregulated & & - \\
\hline \multirow{2}{*}{ Transcription } & upregulated & & 1 \\
\hline & downregulated & & - \\
\hline
\end{tabular}


A total of 3 types of genes were identical. Table 15 shows the result of the analysis. There were 2 types of genes related to growth \& maintenance, 1 type of gene related to response to stress and 1 type of gene related to signal transduction.

\section{Discussion}

There has been a lot of research on preventing apoptosis due to damage because regeneration is difficult once the neuron has been damaged. When a neuron is damaged due to ischemia/hypoxia, along with necrosis in the center, apoptosis in the penumbra occurs ${ }^{17,18)}$. Although apoptosis in the center is unpreventable because it occurs quickly, the penumbra goes through a delayed neuronal death, allowing time to minimize apoptosis ${ }^{19)}$. Delayed neuronal death occurs through diverse mechanisms, but the main process is the production of ROS due to excitotoxicity. In other words, under hypoxia, there is an over-release of glutamate which over -activates the $\alpha$-amino-3-hydroxy-5-methylisoxazole -4-propionic acid (AMPA) receptor and N-methyl-D -aspartate (NMDA) receptor that pass $\mathrm{Ca}^{2+}$, thereby activating the apoptotic protein ${ }^{20,21)}$. When the calcium ion is overly entered into the mitochondria in the neuron, ROS is produced. Because of the overly produced ROS, the permeability of the mitochondria is altered, and the mitochondrial membrane potential (MMP) is lost. As a result, energy (ATP) production is hindered, and apoptosis occurs $^{2,21,22)}$. Meanwhile, the neuron, under hypoxia, operates a self-defense system $^{17)}$ - it boosts angiogenesis, activates apoptosis defense protein and cell survival protein, etc. - in order to protect the neuron ${ }^{23)}$.

Recently, there has been a lot of research on the protective effects on the neuron of herbal medicines or extracts. Most look for pathological mechanisms and gene expression processes under the assumption that a particular protein expression alteration induces a pathological mechanism. However, this method does not consider the mutual interaction between proteins but focuses on the fragmentary role, which makes it difficult to know the overall connection because limited mechanisms can be understood even with the result.

cDNA microarray is a method that looks at large scale gene expression alteration simultaneously by

Table 14. Genes downregulated by Both Woohwangcheongsim-won and Coptis chinensis FRANCH

\begin{tabular}{|c|c|c|c|}
\hline & & Woohwangcheongsim-won & Coptis chinensis $\mathrm{F}_{\mathrm{RANCH}}$ \\
\hline \multirow{2}{*}{ Growth \& maintenance } & upregulated & & \\
\hline & downregulated & & \\
\hline \multirow{2}{*}{ Signal transduction } & upregulated & & \\
\hline & downregulated & & \\
\hline
\end{tabular}

Table 15. Genes Up- or Downregulated by Both Woohwangcheongsim-won and Rheum coreanum NAKAl

\begin{tabular}{|c|c|c|c|}
\hline & & Woohwangcheongsim-won & Rheum coreanum $\mathrm{N}_{\mathrm{AKAI}}$ \\
\hline \multirow{2}{*}{ Growth \& maintenance } & upregulated & - & \\
\hline & downregulated & 2 & \\
\hline \multirow{2}{*}{ Response to stress } & upregulated & & \\
\hline & downregulated & 1 & \\
\hline \multirow{2}{*}{ Signal transduction } & upregulated & 1 & \\
\hline & downregulated & - & \\
\hline
\end{tabular}


using a DNA chip to integrate the gene in high density. It is a high-tech gene analysis method that allows understanding of diverse alterations in a neuron during pathological process at the same time and observation of the overall alteration expression ${ }^{6}$. Also, because cDNA microarray estimates the amount of expression of the gene by the quantitative alteration strength between the experimental group and the control group, it finds the expression direction and the strength of gene expression in a short period of time. Therefore, recently it has been used in diverse bio-science research ${ }^{24}$. Meanwhile, there are many methods to analyze the expression types of genes found from the cDNA microarray results, but to discover the mutual relationship of genes, the clustering method which groups by class according to their functions is often used. In other words, the clustering method has an advantage of knowing the medicine's point of action from a wider point of view because it observes the overall directionality rather than the individual gene $\operatorname{expression}^{25)}$.

There recently has been a lot of research that tries to find the characteristics of herbal medicines or extracts through cDNA microarray. This study compared and analyzed research reports limited to those that observed gene expression alteration through the clustering method in the neuronal hypoxia model among research on the gene expression of herbal medicines using the cDNA microarray method. Target herbal medicines were Acorus gramineus $\mathrm{S}_{\mathrm{OLAND}}{ }^{7}$, Arisaema amurense var. serratum $\mathrm{N}_{\mathrm{AKAI}}{ }^{8)}$, Pinellia ternata B REIT. $^{9}$,', Scutellaria baicalensis $\mathrm{G}_{\mathrm{EORGI}}{ }^{10)}$, Coptis chinensis $\mathrm{F}_{\mathrm{RANCH}}{ }^{11}$, Rheum coreanum $\mathrm{N}_{\mathrm{AKAI}}{ }^{12)}$, Woohwangcheongsim-won ${ }^{13)}$, and Sohaphyang-won ${ }^{14)}$. We interpreted their significance by discovering the genes that were upregulated in common by these medicines through the clustering analysis method of cDNA microarray.

From previous research, it was difficult to find a common ROS-producing cell for Acorus gramineus
Soland, Arisaema amurense var. serratum $\mathrm{N}_{\mathrm{AKAI}}$, Pinellia ternata $\mathrm{B}_{\mathrm{REIT}}$, Scutellaria baicalensis $\mathrm{G}_{\mathrm{EORGI}}$, Coptis chinensis $\mathrm{F}_{\mathrm{RANCH}}$, Woohwangcheongsim-won, and Sohaphyang-won because of excellent ROS removal ability, and they were helpful in maintaining MMP. In the case of Acorus gramineus Soland, Arisaema amurense var. serratum $\mathrm{N}_{\mathrm{AKAI}}$, Scutellaria baicalensis $\mathrm{G}_{\mathrm{EORGI}}$, Woohwangcheongsim-won, and Sohaphyang-won, genes that remove ROS were expressed a lot. For example, in Acorus gramineus $\mathrm{S}_{\mathrm{OLAND}}$, Arisaema amurense var. serratum $\mathrm{N}_{\mathrm{AKAl}}$, Rar $\alpha$ was upregulated, which is a gene that inhibits apoptosis $^{7,8)}$. In research on Woohwangcheongsim -won, Sohaphyang-won, Scutellaria baicalensis $\mathrm{G}_{\mathrm{EORGI}}$, and Arisaema amurense var. serratum $\mathrm{N}_{\mathrm{AKAI}}$, catalase, which is an antioxidant enzyme, was upregulated $^{8,10,13,14)}$. On the other hand, in Pinellia ternata $\mathrm{B}_{\mathrm{REIT}}$., Coptis chinensis $\mathrm{F}_{\mathrm{RANCH}}$, and Rheum coreanum $\mathrm{N}_{\mathrm{AKAI}}$, genes that remove ROS were regulated relatively less than with Acorus gramineus $\mathrm{S}_{\mathrm{OLAND}}$, Arisaema amurense var. serratum $\mathrm{N}_{\mathrm{AKAI}}$, Scutellaria baicalensis $\mathrm{G}_{\mathrm{EORGI}}$, Woohwangcheongsim -won, and Sohaphyang-won; protein tyrosin phosphatase, non-receptor type 11 (Ptpn11) and Cd3 $\delta$ which are cell-supporting genes in their roots, and C-reactive protein (Crp) and platelet-activating factor receptor (Ptafr) which are genes related to the immune system, were upregulated a $\operatorname{lot}^{9,11,12)}$. In research on Pinellia ternata $\mathrm{B}_{\mathrm{REIT}}$, tubulin, beta 5 (Tub $\beta 5$ ), transforming growth factor alpha $(\operatorname{Tgf} \alpha)$, Ptpn11, neuroblastoma ras oncogene (Nras), and platelet-derived growth factor alpha polypeptide $(\operatorname{Pdgf} \alpha)$ which are related to cell growth and differentiation were upregulated ${ }^{9}$. In research on Coptis chinensis $\mathrm{F}_{\mathrm{RANCH}}$, Rheum coreanum $\mathrm{N}_{\mathrm{AKAI}}$, Defb3 which is a response to stress gene was upregulated and nuclear factor-kappaB (Nf- $\kappa$ b) which is related to neuron survival was upregulated $^{11,12)}$.

In the study on Acorus gramineus SOLAND, Arisaema amurense var. serratum $\mathrm{N}_{\mathrm{AKAI}}$ and Pinellia 
ternata $\mathrm{B}_{\mathrm{REIT}}$, which are all medicines that belong to the araceae herb, through the cDNA microarray analysis research of Acorus gramineus $\mathrm{S}_{\mathrm{OLAND}}$ and Arisaema amurense var. serratum $\mathrm{N}_{\mathrm{AKAI}}$, we observed that Akt2, which is known to be the most important gene in cell survival, was commonly upregulated. There were no observed genes that were up- or downregulated commonly when Acorus gramineus $\mathrm{S}_{\mathrm{OLAND}}$, Pinellia ternata $\mathrm{B}_{\mathrm{ReIT}}$, Pinellia ternata $\mathrm{B}_{\text {REIT., }}$ and Arisaema amurense var. serratum $\mathrm{N}_{\mathrm{AKAI}}$ were combined. Also, in Acorus gramineus SolAnd and Coptis chinensis $\mathrm{F}_{\mathrm{RANCH}}$, only Akt2 was commonly upregulated. In sum, Acorus gramineus SOLAND, Arisaema amurense var. serratum $\mathrm{N}_{\mathrm{AKAI}}$, and Coptis chinensis $\mathrm{F}_{\mathrm{RANCH}}$ shared an upregulation of Akt2 [Global $\mathrm{M}=0.9$ (Acorus gramineus $\mathrm{S}_{\mathrm{OLAND}}$ ), 0.6 (Coptis chinensis $\mathrm{F}_{\mathrm{RANCH}}$ ), 0.7 (Arisaema amurense var. serratum $\mathrm{N}_{\mathrm{AKAI}}$ ].

Akt2 is an important gene in cell survival; it inhibits apoptosis in case of myogenic differentiation of serum removal state, and is known to inhibit apoptosis in divided cells ${ }^{26)}$. Therefore, from the fact that Akt2 was commonly upregulated in Acorus gramineus SOLAND, Arisaema amurense var. serratum $\mathrm{N}_{\mathrm{AKAI}}$, and Coptis chinensis $\mathrm{F}_{\mathrm{RANCH}}$, we can infer that these medicines are related to effects of inhibiting apoptosis. Acorus gramineus SOLAND, Arisaema amurense var. serratum $\mathrm{N}_{\mathrm{AKAI}}$, and Coptis chinensis $\mathrm{F}_{\mathrm{RANCH}}$ all have controlled humidity function $^{27)}$, and although it is difficult to conclude the function mechanism by Akt2 alone, it is a gene that should be considered for future research.

In Arisaema amurense var. serratum $\mathrm{N}_{\mathrm{AKAI}}$, Coptis chinensis $\mathrm{F}_{\mathrm{RANCH}}$, and Rheum coreanum $\mathrm{N}_{\mathrm{AKAI}}$, four types of genes including $\mathrm{Nf} \kappa \mathrm{b} 1$ [Global $\mathrm{M}=0.6$ (Arisaema amurense var. serratum $\mathrm{N}_{\mathrm{AKAI}}$ ), 2.0 (Coptis chinensis $\mathrm{F}_{\mathrm{RANCH}}$ ), 1.2 (Rheum coreanum $\mathrm{N}_{\mathrm{AKAI}}$ )], Cd5 [Global M - 1.0 (Arisaema amurense var. serratum $\mathrm{N}_{\mathrm{AKAI}}$ ), 1.7 (Coptis chinensis $\mathrm{F}_{\mathrm{RANCH}}$ ), 0.5 (Rheum coreanum $\mathrm{N}_{\mathrm{AKAI}}$ )], Gng7 [Global $\mathrm{M}=$ 0.8 (Arisaema amurense var. serratum $\mathrm{N}_{\mathrm{AKAI}}$ ), 1.6
(Coptis chinensis $\mathrm{F}_{\mathrm{RANCH}}$ ), 0.6 (Rheum coreanum $\mathrm{N}_{\mathrm{AKAI}}$ )], and Sgne1 [Global $\mathrm{M}=0.7$ (Arisaema amurense var. serratum $\mathrm{N}_{\mathrm{AKAI}}$ ), 0.7 (Coptis chinensis $\mathrm{F}_{\mathrm{RANCH}}$ ), 0.7 (Rheum coreanum $\mathrm{N}_{\mathrm{AKAI}}$ )] were regulated in common. For Nf- $\kappa \mathrm{b}, \mathrm{p} 50$ and p65 that are subunits are activated due to stimulus of glutamic acid in the neuron which accelerates apoptosis or p50, p65, c-Rel subunits are activated due to stimulus of interleukin (IL)- $1 \beta$ which protects from apoptosis ${ }^{28)}$. If the density of inhibitor$\kappa \mathrm{B} \alpha(\mathrm{I} \kappa \mathrm{B} \alpha)$ is decreased, IL- $1 \beta$ stimulates Nf- $\kappa$ $\mathrm{b}$ and protects the neuron ${ }^{29)}$. Caspase 3 , caspase 21 , Bcl2-associated X protein (Bax), which are apoptosis boosting genes, or IL- $1 \beta$, which is an apoptosis inhibiting gene, were not expressed in research of Arisaema amurense var. serratum $\mathrm{N}_{\mathrm{AKAI}}$, Coptis chinensis $\mathrm{F}_{\mathrm{RANCH}}$, and Rheum coreanum $\mathrm{N}_{\mathrm{AKAI}}$. Caspase 2 (Casp2, Global $\mathrm{M}=-0.6$ ) which is an apoptosis related gene was expressed in research of Rheum coreanum $\mathrm{N}_{\mathrm{AKAI}}$. Unlike the caspase family, which is the general apoptosis boosting gene, because casp2 exhibits diverse functions such as acceleration or inhibition of apoptosis ${ }^{30)}$, even with the result of the upregulation of $\mathrm{Nf}-\kappa \mathrm{b}$, it is difficult to infer if the upregulation of Nf- $\kappa b$ boosts or inhibits apoptosis. Guanine nucleotide binding protein, gamma $7(\mathrm{Gn} \gamma 7)$ which is a gene that produces guanine nucleotide binding protein (G protein) is known to exhibit downregulation in esophageal cancer or pancreatic cancer ${ }^{31)}$. In this study, Gn $\gamma 7$ was commonly upregulated in Arisaema amurense var. serratum $\mathrm{N}_{\mathrm{AKAI}}$, Coptis chinensis $\mathrm{F}_{\mathrm{RANCH}}$, and Rheum coreanum $\mathrm{N}_{\mathrm{AKAI}}$. These medicines do not share an identical function from the point of view of Korean Medicine. It is difficult to find a consistent function because we can only infer similar functions such as controlled humidity function (Arisaema amurense var. serratum $\mathrm{N}_{\mathrm{AKAI}}$, Coptis chinensis $\mathrm{F}_{\mathrm{RANCH}}$ ), dispelled Dam-eum (phlegm-retained fluid) (Arisaema amurense var. serratum $\mathrm{N}_{\mathrm{AKAI}}$, Rheum coreanum $\mathrm{N}_{\mathrm{AKAI}}$ ), and 
dispelled Dam-eum (phlegm-retained fluid) (Rheum coreanum $\mathrm{N}_{\mathrm{AKAI}}$ ). However, it is worth considering for future research as multiple genes were commonly expressed. $^{27)}$

For Coptis chinensis $\mathrm{F}_{\mathrm{RANCH}}, 25$ types and 29 types of commonly expressed genes were each observed by the mutual comparison between Coptis chinensis $\mathrm{F}_{\mathrm{RANCH}}$, Arisaema amurense var. serratum $\mathrm{N}_{\mathrm{AKAI}}$ Coptis chinensis $\mathrm{F}_{\mathrm{RANCH}}$, and Rheum coreanum $\mathrm{N}_{\mathrm{AKAI}}$. From the result of Coptis chinensis $\mathrm{F}_{\mathrm{RANCH}}$ and Pinellia ternata $\mathrm{B}_{\mathrm{REIT}}$., only $\mathrm{Cd} 3 \delta$ was expressed commonly and only Woohwangcheongsim -won and Rab-4a, Pdgfr $\alpha$ genes were expressed commonly. In reference to Coptis chinensis $\mathrm{F}_{\mathrm{RANCH}}$, there are combined studies with Scutellaria baicalensis $\mathrm{G}_{\mathrm{EORG}}$, because it is expected to function similarly due to its clear heat effect. There was no gene that was expressed commonly between Scutellaria baicalensis $\mathrm{G}_{\mathrm{EORGI}}$ and Coptis chinensis $\mathrm{F}_{\text {RANCH }}$ in this study. This result lends the possibility that Coptis chinensis $\mathrm{F}_{\mathrm{RANCH}}$ and Scutellaria baicalensis $\mathrm{G}_{\mathrm{EORGI}}$ may function in a different mechanism rather than the clear heat function in the same mechanism. Future research on this aspect is necessary.

From the observation results of common gene expression of Sohaphyang-won and Scutellaria baicalensis $\mathrm{G}_{\mathrm{EORGI}}$, solute carrier family 12, member 1(Slc12a1) [Global M = -0.5 (Sohaphyang-won), -1.1 (Scutellaria baicalensis $\left.\mathrm{G}_{\mathrm{EORGI}}\right)$ ], Scp2 were expressed commonly. Also, from the observation result of Woohwangcheongsim-won and Scutellaria baicalensis $\mathrm{G}_{\mathrm{EORGI}}$ 's gene expression, Tsc2 and Scp2 were found to be expressed commonly. In all Scutellaria baicalensis $\mathrm{G}_{\mathrm{EORG}}$, Woohwangcheongsim -won and Sohaphyang-won, Tsc2 [Global M $=0.7$ (Woohwangcheongsim-won), 0.5 (Sohaphyang-won), 0.6 (Scutellaria baicalensis $\mathrm{G}_{\mathrm{EORGI}}$ ] and Scp2 [Global $\mathrm{M}=-1.3$ (Woohwangcheongsim-won), -0.8 (Sohaphyang-won), $\quad-0.7$ (Scutellaria baicalensis $\left.\mathrm{G}_{\mathrm{EORGI}}\right)$ 's expression alteration was observed.
Tsc2 is a tumor suppressor gene, and it stimulates cell growth when phosphorylated by $\mathrm{Akt}^{32}$. When there is low energy, AMP-activated protein kinase (AMPK) phosphorylates Tsc2 and protects the cell from apoptosis ${ }^{33}$. In this study, in all Woohwangcheongsim -won, Sohaphyang-won and Scutellaria baicalensis $\mathrm{G}_{\mathrm{EORGI}}, \mathrm{Tsc} 2$ was upregulated, and this is identical to the apoptosis inhibiting function. Meanwhile, Scp2 is a DNA combined protein that supports the chromosome structure in the former part of meiosis. It is involved in the transport and metabolism within the cholesterol cell and plays an important role in the production of macrophage foam cell which causes atherosderosis ${ }^{34)}$. Therefore, the downregulation of Scp2 in Woohwangcheongsim-won, Sohaphyang -won, and Scutellaria baicalensis $\mathrm{G}_{\mathrm{EO} G \mathrm{RI}}$ research could be interpreted as a reduction of the lipid moving into the neuron ${ }^{35)}$. Through this study, genes that are commonly expressed were identical in Scutellaria baicalensis $\mathrm{G}_{\mathrm{EORGI}}$ which is an ingredient medicine of Woohwangcheongsim-won and Woohwangcheongsim-won and Sohaphyang-won. Future research should study the gene that is expressed in the identical direction as the function research of the ingredient medicine of Woohwangcheongsim-won or Sohaphyang-won.

4 types of genes - hemoglobin, alpha $1(\mathrm{Hb} \alpha 1)$ [Global $\mathrm{M}=0.9$ (Woohwangcheongsim-won), 1.7 (Sohaphyang-won)], Tsc2, Scp2, and myogenic factor 6 (Myf6) [Global M = -0.6 (Woohwangcheongsim - won), -0.5 (Sohaphyang-won)] - were found to be commonly expressed in the research on Woohwangcheongsim-won and Sohaphyang-won. $\mathrm{Hb}$ $\alpha 1$, which is a type of hemoglobin that has oxygen transport ability, was upregulated in Woohwangcheongsim -won and Sohaphyang-won. This shows an upregulation of oxygen transporter under hypoxia, which means that these medicines have a significant effect in inhibiting apoptosis.

Myf6 is a myocyte differentiation gene and when

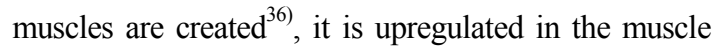


while its expression is limited at the mRNA level ${ }^{37}$. In this study, Myf6 was downregulated in Woohwangcheongsim-won and Sohaphyang-won, but we could not explain the reason the myocyte related gene was expressed in the neuron. Also, it is difficult to find the reason for the downregulation of Slc12a1, which is a cotransporter of $\mathrm{Na}(+)-\mathrm{K}(+)$ $-2 \mathrm{Cl}(-)^{38)}$.

In this study, when expressed genes of Woohwangcheongsim-won and Arisaema amurense var. serratum $\mathrm{N}_{\mathrm{AKAI}}$ were compared, $\operatorname{Rar} \alpha$ was simultaneously upregulated [Global $\mathrm{M}=1.0$ (Woohwangcheongsim-won), 0.6 (Arisaema amurense var. serratum $\mathrm{N}_{\mathrm{AKAI}}$ )]. $\operatorname{Rar} \alpha$ is a receptor in the retinoic acid that is derived from the activation of vitamin A. Retinoic acid is a necessary component in the creation of the nervous system and internal organs, and it is indispensable during the initial creation of the nervous system and the hindbrain ${ }^{39)}$. Based on the finding that $\operatorname{Rar} \alpha$ was upregulated in Woohwangcheongsim-won and Arisaema amurense var. serratum $\mathrm{N}_{\mathrm{AKAI}}$, it appears that it protects the neurons under hypoxia.

When expressed genes of Woohwangcheongsimwon and Coptis chinensis $\mathrm{F}_{\mathrm{RANCH}}$ were compared, Rab4a [Global $\mathrm{M}=-0.6$ (Woohwangcheongsim-won), -0.6 (Coptis chinensis $\mathrm{F}_{\mathrm{RANCH}}$ )] and Pdgfra [Global $\mathrm{M}=-0.6$ (Woohwangcheongsim-won), -1.3 (Coptis chinensis $\left.\left.\mathrm{F}_{\mathrm{RANCH}}\right)\right]$ were commonly downregulated. Early endosome is limited by the gradual activation of PKC and Rab4a, and Rab4a recycles gene endocytic $^{40)}$. It is difficult to find a reasonable explanation for the downregulation of Rab4a in Woohwangcheongsim-won and Coptis chinensis $\mathrm{F}_{\mathrm{RANCH}}$. Pdgfr $\alpha$ is upregulated in medulloblastoma, and by boosting cell division, it creates undivided neuroblasts or neuroglia, thereby being involved in the generation of nerve tumors. The reason this gene is downregulated in Woohwangcheongsim-won and Coptis chinensis $\mathrm{F}_{\mathrm{RANCH}}$ may be related to neuron protection, but it is difficult to explain in more detail $^{41)}$.

When expressed genes of Woohwangcheongsim -won and Rheum coreanum $\mathrm{N}_{\mathrm{AKAI}}$ were compared, phospholipase $\mathrm{C}$ and gamma $1(\mathrm{Plcg} \gamma 1)$ [Global $\mathrm{M}$ $=0.6$ (Woohwangcheongsim-won), 0.8 (Rheum coreanum $\mathrm{N}_{\mathrm{AKAI}}$ ] were commonly upregulated, and phospholipase A2, group IB, pancreas (Pla2g1b) [Global $\mathrm{M}=-0.6$ (Woohwangcheongsim-won), -0.7 (Rheum coreanum $\mathrm{N}_{\mathrm{AKAI}}$ ], and solute carrier family 10, member 1(Slc10a1) [Global $\mathrm{M}=-0.8$ (Woohwangcheongsim-won), -1.3 (Rheum coreanum $\mathrm{N}_{\mathrm{AKAI}}$ ] ] were commonly downregulated.

Plc $\gamma 1$ induces the creation of blood vessels, and the upregulation under hypoxia can be understood as a defense mechanism against cell damage ${ }^{42)}$. Pla2g1b is synthesized in the acinar cell of the pancreas and then released in the intestine during food intake. It is known to accelerate obesity and diabetes by weight loss induced diet ${ }^{43}$. Meanwhile, Slc10al is known to be the transporter of $\mathrm{Na}^{+}$and bile acid ${ }^{44)}$, and it is difficult to explain its downregulation by Woohwangcheongsim-won and Rheum coreanum $\mathrm{N}_{\text {AKAI. }}$.

Thus is the comparison and analysis result of the medicines' characteristics using the clustering analysis method based on the experimental research that compared the gene expression of single herbal treatment and herbal medicines through the cDNA microarray. Despite limitations, through the analysis result of cDNA microarray, we could collect information related to the characteristics of genes commonly expressed between individual herbal treatments or medicines. If we continue the relations analysis research systematically with the herbal medicine mechanism, we hope to better understand the details of the mechanism and the role of herbal treatments and medicines in the future. 


\section{Conclusion}

We found the following conclusions through the comparison and analysis results using the cDNA microarray analysis method and functional clustering method of gene expression alteration due to herbal treatments or single herbal medicines within the apoptosis induced neuron under hypoxia model.

1. Akt2 was upregulated by Acorus gramineus $\mathrm{S}_{\mathrm{OLAND}}$, Arisaema amurense var. serratum $\mathrm{N}_{\mathrm{AKAI}}$ and Coptis chinensis $\mathrm{F}_{\mathrm{RANCH}}$, and they belong to Araceae herb.

2. Nf- $\kappa$ b1, Cd5, Gn $\gamma 7$ and Sgne1 were upregulated by Arisaema amurense var. serratum $\mathrm{N}_{\mathrm{AKAI}}$, Coptis chinensis $\mathrm{F}_{\mathrm{RANCH}}$ and Rheum coreanum $\mathrm{N}_{\text {AKAI }}$.

3. Woohwangcheongsim-won, Sohaphyang-won and Scutellaria baicalensis $\mathrm{G}_{\mathrm{EORGI}}$ downregulated Scp2, and upregulated Tsc2. Woohwangcheongsim -won and Sohaphyang-won upregulated Hbal, and downregulated Myf6.

4. Sohaphyang-won and Scutellaria baicalensis GEORGI downregulated Slc12a1.

5. Woohwangcheongsim-won and Arisaema amurense var. serratum $\mathrm{N}_{\mathrm{AKAI}}$ upregulated $\operatorname{Rar} \alpha$, Woohwangcheongsim-won and Coptis chinensis $\mathrm{F}_{\text {RANCH }}$ downregulated Rab5a and $\operatorname{Pdgfr} \alpha$, and Woohwangcheongsim-won and Rheum coreanum $\mathrm{N}_{\mathrm{AKAI}}$ upregulated Plc $\gamma 1$ and downregulated Pla2g1b and Slc10a1.

\section{References}

1. Honig LS, Rosenberg RN. Apoptosis and neurologic disease. Am J Med. 2000;108(4): 317-30.

2. Rego AC, Oliveira CR. Mitochondrial Dysfunction and Reactive Oxygen Species in Excitotoxicity and Apoptosis: Implications for the Pathogenesis of Neurodegenerative Diseases. Neurochem Res. 2003;28(10):1563-74.

3. International Human Genome Sequencing Consortium. Initial sequencing and analysis of the human genome. Nature. 2001;209:860-921.

4. Arabidopsis Genome Initiative. Analysis of the genome sequence of the flowering plant Arabidopsis thaliana. Nature. 2000;408:796-815.

5. Tanaka TS, Jaradat SA, Lim MK, Kargul GJ, Wang X, Grahovac MJ, et al. Genome-wide expression profiling of mid-gestation placenta and embryo using a 15,000 mouse developmental cDNA microarray. Proc Natl Acad Sci USA. 2000;97:9127-32.

6. Harrington CA, Rosenow C, Retief J. Monitoring gene expression using DNA microarrays. Curr Opin Microbiol. 2000;3:285-91.

7. Park DJ, Jung SH, Moon IS, Lee WC, Shin GC. Microarray Analysis of Alteration in Gene Expression by Acori graminei rhizoma (AGR) Water-Extract in a Hypoxic Model of Cultured Rat Cortial Cells. J Life Science. 2007;17(1) :150-61.

8. Koh KD. Effects of Arisaema amurense var. serratum NAKAI(南星) on the modulation of ROS, MMP and Gene Expression in a Hypoxic Model of Cultured Rat Cortical Cells. The graduate school of Dongguk Uni. 2003.

9. Kwon GR. Rizoma(牛夏) on Prevention of Cortical Neuronal Cell Death and Gene Expression. The graduate school of Dongguk Uni. 2005.

10. Kim SB, Chung SH, Shin GC, Lee WC. Effects of Scutellaria baicalensis GEORGI on Gene Expression in a Hypoxic Model of Cultured Rat Cortical Cells. Korean J Orient Int Med. 2004; 25(4-2):324-36.

11. Hwang JW, Kim KH, Shin GC, Moon IS. Efeects of Gene Expression by Coptidis chinesis 
FRANCH. in a Hypoxic Model of Cultured Rat Cortical Cells. Korean $J$ Orient Int Med. 2011;32(2):301-21.

12. Lee HS, Lee JY, Moon IS. Microarray Analysis of Gene Expression by Rhei Rhizoma Water Extracts in a Hypoxia Model of Cultured Neurons. J Life Sci. 2009;19(1):21-33.

13. Park DW, Kim WS, Bae $\mathrm{CH}$, Jeong SH, Shin GC, Lee WC. Effects of Woohwangcheongsim -won Gene Expression in a Hypoxic Model of Cultured Rat Cortical Cells. J Korean Oriental Med. 2004;25(3):123-36.

14. Paik JW, Lee YH, Kim WS, Jeong SH, Shin GC, Lee WC. Effects of Sohaphyang-won Gene Expression in a Hypoxic Model of Cultured Rat Cortical Cells. $J$ Korean Oriental Med. 2004;25(2):127-37.

15. Sturn A, Quackenbush J, Trajanoski Z. Genesis: cluster analysis of microarray data. Bioinformatics. 2002;18(1):207-8.

16. Eisen MB, Spellman PT, Brown PO, Botstein D. Cluster analysis and display of genome-wide expression patterns. Proc Natl Acad Sci USA. 1998;95(25):14863-8.

17. Zimmermann KC, Green DR. How cells die: Apoptosis pathways. J Allergy Clin Immunol. 2001;108(4):99-103.

18. Hochachka PW, Lutz PL. Mechanism, origin, and evolution of anoxia tolerance in animals. Comp Biochem Physiol B: Biochem Mol Biol. 2001;130(4):435-59.

19. Won MH. Noeheohyeole Uihan Jiyeonseong Singyeongseposaui Gijeon. Biochemistry News. 2002;22(2):158-68.

20. Banasiaka KJ, Xiab Y, Haddad GG. Mechanisms underlying hypoxia-induced neuronal apoptosis. Prog Neurobiol. 2000;62(3):215-49.

21. Wang H, Yu SW, Koh DW, Lew J, Coombs C, Bowers W, et al. Apoptosis-Inducing Factor
Substitutes for Caspase Executioners in NMDA-Triggered Excitotoxic Neuronal Death. J. Neurosci. 2004;24(48):10963-73.

22. Nieminen AL. Apoptosis and necrosis in health and disease: Role of mitochondria. Int Rev Cytol. 2003;224:29-55.

23. Oosthuyse B, Moons L, Storkebaum E, Beck H, Nuyens D, Brusselmans K, et al. Deletion of the hypoxia-response element in the vascular endothelial growth factor promoter causes motor neuron degeneration. Nature Genet. 2001;28: 131-8.

24. Oh MK. Research Trends of Bioinformatics Using DNA Microarray Data. Pros Ind Chem. 2006;9(5):43-8.

25. Shih JH, Michalowska AM, Dobbin K, Ye Y, Qiu TH, Green JE. Effects of pooling mRNA in microarray class comparisons. Bioinformatics. 2004;20(18):3318-25.

26. Fujio Y, Mitsuuchi Y, Testa JR, Walsh K. Activation of Akt2 Inhibits anoikis and apoptosis induced by myogenic differentiation. Cell Death Differ. 2001;8(12):1207-12.

27. Sinmunpungchulpangongsa. Sinpyeonjungyakdaesajeon. Chopan. 1981:113-9,333-7,2107-16.

28. Pizzi M, Goffi F, Boroni F, Benarese M, Perkins $\mathrm{SE}$, Liou HC, et al. Opposing Roles for NF- $\kappa$ B/Rel Factors p65 and c-Rel in the Modulation of Neuron Survival Elicited by Glutamate and Interleukin-1 $\beta . J$ Biol Chem. 2002;277:20717 -23 .

29. Pizzi M, Sarnico I, Boroni F, Benetti A, Benarese $\mathrm{M}$, Spano PF. Inhibition of $\mathrm{I} \kappa \mathrm{B} \alpha$ phosphorylation prevents glutamate-induced NF- $\kappa \mathrm{B}$ activation and neuronal cell death. Acta Neurochir. 2005;93:59-63.

30. Krumschnabel G, Sohm B, Bock F, Manzl C, Villunger A. The enigma of caspase-2: the laymen's view. Cell Death Differ. 2009;16: 
195-207.

31. Ohta1 M, Mimori K, Fukuyoshi Y, Kita Y, Motoyama K, Yamashita K, et al. Clinical significance of the reduced expression of $\mathrm{G}$ protein gamma 7 (GNG7) in oesophageal cancer. Brit J Cancer. 2008:98;410-7.

32. Inoki $\mathrm{K}, \mathrm{Li} \mathrm{Y}, \mathrm{Zhu} \mathrm{T}$, Wu J, Guan KL. TSC2 is phosphorylated and inhibited by Akt and suppresses mTOR signalling. Nat Cell Biol. 2002;4:648-57.

33. Inoki $\mathrm{K}$, Zhu T, Guan KL. TSC2 Mediates Cellular Energy Response to Control Cell Growth and Survival. Cell. 2003;115(5): 577-90.

34. Offenberg HH, Schalk JAC, Meuwissen RLJ, Aalderen M, Kester HA, Dietrich AJJ, Heyting C. SCP2: A major protein component of the axial elements of synaptonemal complexes of the rat. Nucl Acids Res. 1998;26(11):2572-9.

35. Liang WS, Dunckley T, Beach TG, Grover A, Mastroeni D, Walker DG, et al. Gene expression profiles in anatomically and functionally distinct regions of the normal aged human brain. Physiol Genomics. 2007;28:311-22.

36. Kassar-Duchossoy L, Gayraud-Morel B, Gomès D, Rocancourt D, Buckingham M, Shinin V, et al. Mrf4 determines skeletal muscle identity in Myf5: Myod double-mutant mice. Nature. 2004;431:466-71.

37. Hinitsa Y, Osborna DPS, Carvajalb JJ, Rigbyb PWJ, Hughes SM. Mrf4 (myf6) is dynamically expressed in differentiated zebrafish skeletal muscle. Gene Expression Patterns. 2007;7(7): 738-45.

38. Hannemann A, Christie JK, Flatman PW. Functional Expression of the $\mathrm{Na}-\mathrm{K}-2 \mathrm{Cl}$
Cotransporter NKCC2 in Mammalian Cells Fails to Confirm the Dominant-negative Effect of the AF Splice Variant. J Biol Chem. 2004;284: 35348-58.

39. Gavalas A, Krumlauf R. Retinoid signalling and hindbrain patterning. Curr Opin Genet Dev. 2000;10(4):380-6.

40. Hellberg C, Schmees C, Karlsson S, Åhgren A, Heldin $\mathrm{CH}$. Activation of Protein Kinase C Is Necessary for Sorting the PDGF $\beta$-Receptor to Rab4a-dependent Recycling. Mol Biol Cell. 2009;20:2856-63.

41. MacDonald TJ, Brown KM, LaFleur B, Peterson $\mathrm{K}$, Lawlor C, Chen Y, et al. Expression profiling of medulloblastoma: PDGFRA and the RAS/MAPK pathway as therapeutic targets for metastatic disease. Nat Genet. 2001;29:143-52.

42. Lawson ND, Mugford JW, Diamond BA, Weinstein BM. phospholipase C gamma-1 is required downstream of vascular endothelial growth factor during arterial development. Genes Dev. 2003;17:1346-51.

43. Hui DY, Cope MJ, Labonté ED, Chang H-T, Shao J, Goka E, et al. The phospholipase A2 inhibitor methyl indoxam suppresses diet-induced obesity and glucose intolerance in mice. Brit $J$ Pharmacol. 2009;157(7):1263-9.

44. Mita S, Suzuki H, Akita H, Hayashi H, Onuki $\mathrm{R}$, Hofmann AF, et al. Inhibition of Bile Acid Transport across $\mathrm{Na}+$ /Taurocholate Cotransporting Polypeptide (SLC10A1) and Bile Salt Export Pump (ABCB 11)-Coexpressing LLC-PK1 Cells by Cholestasis-Inducing Drugs. Drug Metab Dispo. 2009;34(9):1575-81. 